\title{
Pengembangan Modul Berbasis Multimedia Dengan Menggunakan Flip PDF Professional Pada Tema Udara Yang Sehat
}

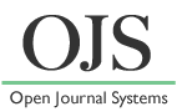

\author{
Siti Chusni Nurlatifah", Siti Romlah Noer Hodijah, Adi Nestiadi \\ Program Studi Pendidikan IPA, FKIP, Universitas Sultan Ageng Tirtayasa \\ *Email: chusninurlatifah09@gmail.com
}

DOI: https://doi.org/10.33369/pendipa.6.1.226-232

\begin{abstract}
The Flip PDF Professional multimedia-based learning module is a learning module in which there are several learning activities, so as to help students achieve learning objectives. This module is presented in multimedia form using the Flip PDF Professional application, the resulting product is an attractive flipbook because it can contain images, videos, animations, audio and text that can be flipped while reading it. The purpose of this research is to develop and determine the level of validity of the learning modules that have been made. This research was conducted at three junior high schools in the city of Serang with a period of August 2020 to August 2021. The research method used was Research and Development $(R \& D)$ with a model development design adapted from Sugiyono, namely through stages (1) potential and problems, (2) data collection, (3) product design, (4) design validation, and (5) design improvement. The instrument used is a validation sheet for the validity test which will be carried out by two media experts, two material experts, and also three science teachers. The results of the validity test of the multimedia-based module using Flip PDF Professional on the healthy air theme based on media validation got a score of $89.4 \%$ with a very valid category, and for material validation it got a value of $86.9 \%$ which means it is in the very valid category.
\end{abstract}

Keywords: Learning Module; Multimedia; Flip PDF Professional; Healthy Air Theme.

\begin{abstract}
ABSTRAK
Modul pembelajaran berbasis multimedia Flip PDF Professional merupakan modul pembelajaran yang di dalamnya terdapat beberapa kegiatan pembelajaran, sehingga membantu siswa mencapai tujuan pembelajaran. Modul ini disajikan dalam bentuk multimedia dengan menggunakann aplikasi Flip PDF Professional, produk yang dihasilkan berupa flipbook yang menarik karena dapat memuat gambar, video, animasi, audio dan teks yang dapat dibolak-balik saat membacanya. Tujuan dari penelitian ini yaitu mengembangkan dan mengetahui tingkat kevalidan modul pembelajaran yang telah dibuat. Penelitian ini dilakukan pada tiga SMP di kota Serang dengan kurun waktu bulan Agustus 2020 sampai dengan Agustus 2021. Metode penelitian yang digunakan adalah Research and Development (R\&D) dengan desain pengembangan model yang diadaptasi dari Sugiyono yaitu melalui tahapan (1) potensi dan masalah, (2) pengumpulan data, (3) desain produk, (4) validasi desain, dan (5) perbaikan desain. Instrumen yang digunakan adalah lembar validasi untuk uji kevalidan yang akan dilakukan oleh dua ahli media, dua ahli materi, dan juga tiga Guru IPA. Hasil uji kevalidan modul berbasis multimedia dengan menggunakan Flip PDF Professional pada tema udara yang sehat ini berdasarkan validasi media mendapatkan nilai $89,4 \%$ dengan kategori sangat valid, dan untuk validasi materi mendapatkan nilai $86,9 \%$ yang berarti masuk ke dalam kategori sangat valid.
\end{abstract}

Kata kunci: Modul Pembelajaran; Multimedia; Flip PDF Professional; Tema Udara yang Sehat.

\section{PENDAHULUAN}

IPA (Ilmu Pengetahuan Alam) merupakan pelajaran yang berkaitan sangat erat dengan manusia. Hal tersebut dikarenakan dalam hidup manusia sangat bergantung pada alam, zat yang ada di alam, serta semua yang terjadi di alam. 
(Wisudawati dan Sulistyowati, 2014). Pembelajaran kurikulum 2013, pelajaran IPA pada jenjang Sekolah Menengah Pertama (SMP) dikembangkan secara terpadu, yaitu dengan menyatukan beberapa konsep IPA meliputi fisika, kimia, biologi, serta IPBA (Wulandari, dkk., 2018). Salah satu model keterpaduan yaitu model keterpaduan Integrated, model keterpaduan integrated merupakan keterpaduan yang memadukan atau mencampurkan beberapa materi pembelajaran yang saling tumpang tindih atau beririsan (Karli, 2013). Pembelajaran keterpaduan dilakukan dengan menggunakan tema, tema ini memadukan konsep dari bidang biologi, fisika, dan IPBA. Dalam penelitian ini penyusunan tema dilakukan dengan mengangkat tema Udara yang Sehat, dimana pada tema tersebut terdapat konsep IPBA yaitu pencemaran udara, kimia yaitu mengenai zat gas, dan juga biologi yaitu mengenai gangguan sistem pernapasan.

Tema udara sehat ini terdiri atas materi yang terdapat pada pembelajaran IPA dan merupakan keterpaduan dari materi kelas VII dan VIII yang saling beririsan. Berdasarkan model keterpaduan yang digunakan oleh peneliti yaitu Integrated, yang artinya model keterpaduan yang membelajarkan beberapa Kompetensi Dasar (KD) yang terdiri dari materi yang beririsan/berkaitan. Adapun KD yang akan dibahas adalah KD 3.3 kelas VII yaitu mengenai zat dan karakteristiknya, dimana yang akan dibahas hanyalah mengenai zat gas, KD selanjutnya yaitu KD 3.8 kelas VII mengenai pencemaran lingkungan, dimana yang akan dibahas hanya mengenai materi pencemaran udara. Selain KD kelas VII penelitian ini juga menggunakan KD kelas VIII yaitu KD 3.9 mengenai sistem pernapasan, pada KD ini yang akan dibahas mengenai mekanisme pertukaran udara pada manusia.

Pada proses pembelajaran terdapat interaksi yang terjadi antara siswa dan guru. Hal tersebut dikarenakan siswa dan guru merupakan unsur dari kegiatan pembelajaran. Selain guru dan siswa, alat bantu pembelajaran atau bahan ajar juga merupakan unsur pembelajaran (Rahayu dan Sudarmin, 2015). Modul sebaiknya diawali dengan materi sederhana agar siswa dapat memahai yang sulit, dari materi sederhana menuju pada materi yang kompleks sehingga siswa belajar secara tahap demi tahap. (Depdiknas, 2010).

Guru harus mempersiapkan bahan ajar sebelum memulai pembelajaran, karena bahan ajar tersebut akan membantu guru mencapai tujuan pembelajaran. Modul yaitu salah satu bahan ajar yang sesuai untuk digunakan oleh guru pada suatu pembelajaran (Rahayu dan Sudarmin, 2015).

Modul adalah bahan ajar yang dibuat secara lengkap dan di dalamnya berisi suatu pembelajaran yang disusun dan diatur agar dapat membantu mencapai tujuan pembelajaran (Pratiwi dan Martiana, 2017). Menurut Daryanto (2013) yang termasuk ke dalam karakteristik yang harus dimiliki modul ialah (1) Self Instruction, yakni dengan karakteristik siswa dapat belajar mandiri serta tidak bergantung dengan media lain, (2) Self Contained, yaitu mencakup semua bahasan yang diperlukan pada pembelajaran. Karakteristik ini berguna agar siswa dapat mempelajari suatu materi secara lengkap dengan menggunakan modul, (3) Stand Alone, yakni berdiri sendiri atau tidak menjadikan media lain sebagai acuan. Sehingga siswa tidak perlu menggunakan media lain cukup dengan modul saja, (4) Adaftive, yaitu dengan karakteristik ini modul diharapkan dapat beradaptasi dengan perkembangan ilmu serta teknologi, sehingga modul pembelajaran dapat mengikuti perkembangan teknologi dan ilmu pengetahuan, dan (5) User Friendly, yaitu karakteristik yang berarti bersahabat dengan pengguna. Segala informasi ataupun petunjuk yang disampaikan harus dapat membantu pengguna, misalnya penggunaan bahasa yang sederhana, dapat dipahami, serta menggunaakan bahasa yang umum. Pada cara penggunaan modul pembelajaran sebaiknya disampaikan dengan jelas agar siswa dapat mengikuti segala proses pembelajaran yang ada pada modul.

Menerapkan pemakaian TIK (Teknologi Infermasi dan Komunikasi) sangat diperlukan pada suatu pembelajaran, salah satunya dengan penggunaan internet. Karena salah satu faktor yang dapat mempercepat penyampaian ilmu pengetahuan kepada siswa yaitu dengan menggunakan teknologi (Tania, 2017).

Dunia sedang dilanda pandemi yang disebabkan oleh Virus Corona. Salah satu dampak pandemi ini ialah terhadap pendidikan, 
yang mengarah penutupan sekolah dan mengoordinasikan pembelajaran melalui sistem daring atau online (Pakpahan dan Fitriani, 2020).

Hasil dari wawancara kepada guru IPA pada tiga SMP di Kota Serang, diperoleh hasil bahwa biasanya bahan ajar yang digunakan adalah dari kemendikbud dan masih jarang menggunakan modul pembelajaran. Adapun modul yang sering digunakan yaitu modul pembelajaran berbentuk cetak dan sudah jadi yang biasa dikenal dengan LKS. Kekurangan modul yang biasa digunakan yaitu karena bentuknya berupa cetak sehingga kurang mendukung proses pembelajaran diera pandemi saat ini, guru juga sebelumnya belum pernah menggunakan modul dalam bentuk lain dan juga belum mengenal modul dengan basis multimedia.

Sistem pembelajaran yang digunakan saat ini masih banyak yang bersifat monoton, kurangnya media teknologi komunikasi yang menarik dalam penyampaian materi membuat mahasiswa cepat jenuh (Sulistiyawati, dkk., 2017). Maka perlu dilakukan pengembangan modul pembelajaran multimedia, dengan modul multimedia ini pembelajarannya meliputi teks, grafis, foto, animasi video dan suara sehingga pembelajaran menjadi lebih menarik (Indriana, 2011).

Seiring dengan perkembangan teknologi informasi dan dengan berbagai cara dapat membuat pembelajaran tetap terhubung meskipun berada dalam ruangan yang berbeda. Sehingga proses pembelajaran tetap dapat dilakukan dengan memanfaatkan teknologi yang ada (Pakpahan dan Fitriani, 2020). Ada beberapa software ataupun aplikasi yang bisa dipakai untuk membuat bahan ajar diantaranya yakni Flip PDF Professional. Software ini aplikasi dengan kegunaan pembuat e-book yang berbentuk flipbook yang dilengkapi dengan beberapa jenis multimedia misalnya animasi flash, audio, dan video. Kelebihan dari software ini yaitu bahan ajar yang dibuat merupakan bahan ajar interaktif dan menarik (Sriwahyuni, dkk., 2019), dapat dengan mudah digunakan untuk yang belum memahami HTML (Seruni, dkk., 2019), output dari aplikasi ini juga dapat dipublish secara online maupun offline (Arsal, dkk., 2019). Dengan modul yang berupa flipbook ini proses pembelajaran akan berjalan dengan efisien karena tidak hanya dapat dilakukan di dalam kelas, namun juga dapat diakses di luar kelas yaitu melalui smartphone (Putri, dkk., 2022).

Berdasarkan paparan tersebut maka perlu dilakukan Pengembangan Modul Berbasis Multimedia Dengan Menggunakan Flip PDF Professional Pada Tema Udara yang Sehat. Penelitian ini mempunyai beberapa rumusan masalah, diantaranya yaitu (1) bagaimana pengembangan modul berbasis multimedia menggunakan Flip PDF Professional pada tema Udara yang Sehat?, dan (2) bagaimana kevalidan modul berbasis multimedia menggunakan Flip PDF Professional pada tema udara yang sehat?

\section{METODE PENELITIAN}

Penelitian ini dilakukan dengan menerapkan metode R\&D (Research and Development). yaitu metode yang dipakai untuk pengembangan produk ataupun untuk penyempurnaan produk yang ada agar bisa dipertanggung jawabkan. Informasi yang berupa data-data diperoleh dengan research dan development dilakukan untuk memperoleh atau mengembangkan perangkat pembelajaran (Sugiyono, 2013).

Penelitian ini dilaksanakan pada tiga SMP di Kota Serang dengan kurun waktu bulan Agustus 2020 sampai dengan Agustus 2021. Model pengembangan yang dilakukan yaitu model pengembangan Sugiyono (2013) dengan lima tahap pengembangan. Berikut tahap pengembangan yang dilaksanakan:

\section{Tahap Potensi dan Masalah}

Potensi dan masalah ini dilakukan melalui wawancara tiga orang guru IPA ditiga sekolah yaitu SMPN 9 Kota Serang, SMPN 14 Kota Serang, dan SMPN 17 Kota Serang. Kegiatan ini mempunyai tujuan agar dapat mengetahui potensi dan masalah menyangkut tentang modul sehingga dapat memenuhi kebutuhan pembelajaran siswa pada materi IPA. Dari wawancara tersebut didapatkan bahwa buku ajar dari kemendikbud merupakan bahan ajar yang sering digunakan juga jarang menggunakan modul. Adapun modul yang sering digunakan yaitu modul berbentuk cetak dan sudah jadi yang biasa dikenal dengan LKS. Kekurangan modul yang biasa digunakan yaitu karena bentuknya berupa cetak sehingga kurang mendukung proses pembelajaran diera pandemi saat ini, guru juga 
sebelumnya belum pernah menggunakan modul dalam bentuk lain dan juga belum mengenal modul pembelajaran dengan basis multimedia.

\section{Tahap Pengumpulan Data}

Data diperoleh dengan mengumpulkan kajian pustaka berkaitan dengan modul, pembelajaran multimedia, aplikasi Flip PDF Professional serta materi IPA.

Aplikasi Flip PDF Professional memiliki kegunaan untuk membuat $e$-book yang berbentuk flipbook dengan dilengkapi beberapa jenis multimedia misalnya animasi flash, audio, dan video (Sriwahyuni, dkk., 2019), Untuk materi yang digunakan pada modul ini diperoleh dari berbagai sumber yaitu dari buku dan juga jurnal (online maupun offline) yang disesuaikan dengan kebutuhan kurikulum. Materi tersebut berisi deskripsi mengenai Udara yang Sehat yang terdiri atas materi mengenai udara, pencemaran udara, dan mekanisme pertukaran udara pada manusia.

\section{Tahap Desain Produk}

Tahap ini dimulai dengan membuat modul menggunakan Microsoft powerpoint, dan kemudian dikonversi menjadi format PDF agar dapat dioperasikan pada aplikasi Flip PDF Professional. File yang berbentuk PDF dapat dioperasikan pada aplikasi Flip PDF Professional dan otomatis mejadi flipbook. Setelah dalam aplikasi Flip PDF Professional ditambahkan juga beberapa video pembelajaran yang menarik guna menambah wawasan siswa dalam proses pembelajaran, selain menambahkan video pada proses pembuatan modul dengan menggunakan aplikasi ini juga soal evaluasi dibuat secara interaktif, yaitu siswa dapat memilih jawaban langsung pada modul tersebut dan mengetahui jawabannya.

\section{Tahap Validasi Desain}

Validasi desain ini, terdapat beberapa penilaian yaitu validasi oleh ahli materi (Dosen dari Universitas Sultan Ageng Tirtayasa), ahli media (Dosen dari Universitas Sultan Ageng Tirtayasa), dan penilaian guru IPA (SMPN 9 Kota Serang, SMPN 14 Kota Serang, dan SMPN 17 Kota Serang) yang akhirnya dapat diketahui kekurangan dari desain produk yayng dikembangkan.
Penelitian ini menggunakan angket sebagai Teknik pengumpulan datanya. Yakni angket validasi media dan materi. Pada penelitian ini juga menggunakan analisis data yakni teknis analisis deskriptif kuantitatif serta deskriptif kualitatif, yang berarti data yang didapatkan melalui penelitian ini yaitu data kualitatif dianalisis menggunakan data kuantitatif, yang berupa angka serta dijelaskan dalam bentuk katakata. Instrumen yang digunakan pada penelitian ini yakni angket dengan skala likert. Skala likert ini dipakai sebagai alat ukur sikap,persepsi, serta pendapat mengenai fenomena sosial (Sugiyono, 2013). Penelitian pengembangan ini menggunakan skala 1 sampai 5, dengan aturan pada Tabel 1.

Tabel 1. Aturan pemberian Skor

\begin{tabular}{cc}
\hline Kategori & Skor \\
\hline SB (Sangat Baik) & 5 \\
B (Baik) & 4 \\
C (Cukup) & 3 \\
K (Kurang) & 2 \\
SK (Sangat Kurang) & 1 \\
\hline
\end{tabular}

(Sugiyono, 2013)

Kemudian ditentukan skornya dengan rumus berikut:

$$
\frac{\text { Skor yang diperoleh }}{\text { jumlah Skor }} \times 100 \%
$$

Hasil nilai validasi media dan validasi materi selanjutnya ditentukan nilai rata-ratanya kemudian diubah menjadi pernyataan penilaian untuk menentukan kevalidan produk dengan skala berikut:

Tabel 2. Skala Kevalidan Modul

\begin{tabular}{cc}
\hline Skor & Kategori \\
\hline $0-20 \%$ & Sangat Kurang Valid \\
$21 \%-40 \%$ & Kurang Valid \\
$41 \%-60 \%$ & Cukup Valid \\
$61 \%-80 \%$ & Valid \\
$81 \%-100 \%$ & Sangat Valid \\
\hline
\end{tabular}

(Sugiyono, 2013)

\section{Tahap Perbaikan Desain}

Tahap ini dilakukan dengan memperbaiki modul sesuai dengan saran yang telah diberikan 
oleh ahli. Tujuan dari perbaikan desain ini yaitu untuk meminimalkan kekurangan produk yang dikembangkan sehingga menghasilkan produk akhir yaitu modul pembelajaran berbasis multimedia dengan menggunakan Flip PDF Professinal pada tema udara yang sehat.

\section{HASIL DAN PEMBAHASAN}

Modul pembelajaran berbasis multimedia dengan menggunakan Flip PDF Professional pada tema udara yang sehat merupakan hasil dari penelitian mengembangan ini. Penelitian ini dilaksanakan untuk mengukur tingkat kevalidan modul pembelajaran yang telah dikembangkan. Berikut hasil validasi media dan materi berdasarkan validator:

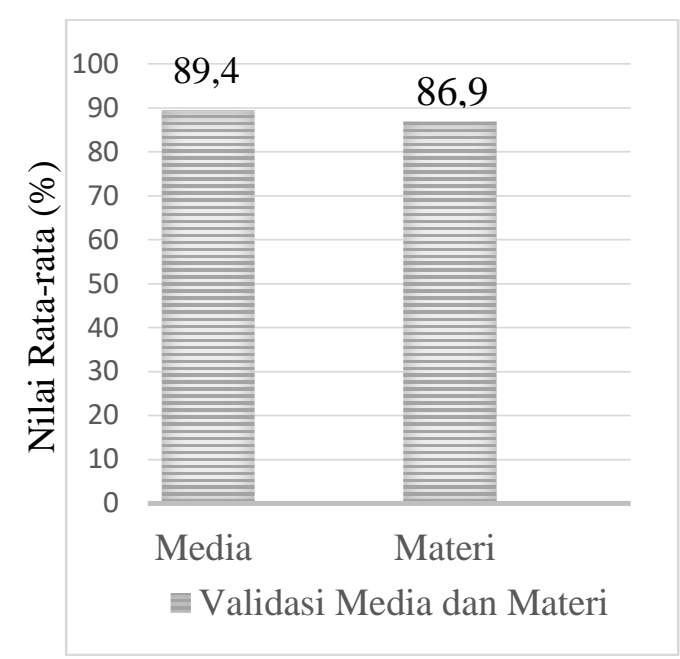

Gambar 1. Hasil Validasi Produk

\section{Hasil Validasi Media}

Gambar 1 menunjukkan bahwa berdasarkan penilaian validator, validasi media mendapatkan nilai $89,4 \%$ dengan kategori sangat valid. Validasi media didasarkan pada tiga aspek yaitu aspek tempilan media, kemudahan media dan manfaat media.

Pada aspek tampilan media ini validator sudah memberikan nilai sangat baik karena cover pada modul sudah mewakili isi modul secara keseluruhan, untuk warna background modul pembelajaran ini menggunakan warna putih dengan tambahan warna biru sehingga memiliki kekontrasan yang baik dengan teks yang berwarna gelap (hitam). Hal ini sejalan dengan pendapat Priambudi (2018) bahwa template warna yang digunakan harus bersifat kontras, yang artinya perbedaan warna pada background dan tulisan harus kontras yang bertujuan agar memudahkan siswa dalam membaca dan memahami pembelajaran. Kontras juga berarti membuat perbedaan antarelemen yang ada pada modul. Untuk penggunaan huruf pada modul ini tidak berlebihan yakni menggunakan jenis huruf Comic Sans MS huruf tersebut dapat memberikan kesan yang santai dan tidak kaku. Menurut Priambudi (2018) Font atau jenis huruf adalah salah satu faktor penting yang membuat pesan atau materi dalam modul dapat dengan mudah tersampaikan kepada siswa.

Untuk gambar dan video pada modul dapat dilihat dan diputar dengan jelas, Gambar dan video ini juga dapat memperjelas konsep yang dipelajari, hal ini sejalan dengan pendapat Hasanah dan Nulhakim (2015) bahwa gambar dan video pembelajaran harus mampu memperjelas konsep yang disajikan serta memiliki peran komunikatif dalam tampilannya. Manurut Priambudi (2018) Dalam pembuatan modul juga harus dapat memilih gambar dan video yang sesuai dengan tema yang diangkat, dengan demikian maka akan memudahkan ketersampaian pembelajaran yang baik kepada siswa. Adapun saran dari validator mengenai aspek tampilan media ini yaitu sebaiknya pada cover cantumkan nama penyusun, dan kontras gambar perlu diperjelas

Pada aspek kemudahan media, validator memberi nilai sangat baik karena modul dapat dengan mudah digunakan yaitu untuk membalikkan halaman cukup dengan menyeret sudut, mengklik ikon yang tersedia, dan juga dapat dengan menggunakan roda mouse (Flipbuilder, 2020). Menurut Daryanto (2013) modul sebaiknya memiliki karakteristik User Friendly, yaitu karakteristik yang berarti bersahabat dengan pengguna. Segala informasi ataupun petunjuk yang disampaikan harus dapat membantu pengguna, misalnya modul menggunakan bahasa yang sederhana, dapat dipahami, serta menggunaakan bahasa yang umum. Pada cara penggunaan modul pembelajaran sebaiknya disampaikan dengan jelas agar siswa dapat mengikuti segala proses pembelajaran yang ada pada modul. Adapun saran yang diberikan oleh validator yaitu perlu diperhatikan kembali bagian petunjuk 
penggunaan terutama bagian ikon next, back, dan close.

Pada aspek manfaat media ini sebagian besar validator memberikan nilai yang sangat baik. Karena pada modul pembelajaran bisa dioperasikan kembali oleh siswa secara online, menarik minat belajar siswa, serta dapat pula digunakan secara mandiri. Berdasarkan karakteristik modul yakni self instruction yang berarti siswa dapat mengoperasikan modul dengan mandiri serta tidak memerlukan bantuan pihak lain (Daryanto, 2013).

\section{Hasil Validasi Materi}

Gambar 1 menunjukkan bahwa berdasarkan penilaian validator, validasi materi mendapatkan nilai $86,9 \%$ dengan kategori sangat valid. Pada validasi ini terdapat beberapa aspek diantaranya yakni aspek penyajian, isi, serta kebahasaan.

Pada aspek penyajian ini validator sudah memberikan nilai yang baik, karena dilihat dari materi sudah runtut, dan penyajian tampilan keseluruhan juga sudah baik. Adapun saran yang diberikan yaitu mengenai konsistensi sistematika modul ini perlu diperbaiki. Aspek penyajian ini sesuai dengan pendapat Depdiknas (2010) yaitu bahan ajar sebaiknya disusun secara sistematis yaitu dimulai dari yang sederhana untuk memahami yang sulit sehingga siswa dapat belajar secara bertahap.

Dilihat dari aspek isi sebagian besar validator sudah memberikan nilai yang baik, karena pada modul ini sudah terdapat KI \& KD, indikator, materi yang disertai LKS, dan juga evaluasi pembelajaran. Hal tersebut sejalan dengan arti dari modul itu sendiri, yaitu bahan ajar yang dirancang secara lengkap yang di dalamnya berisi suatu pembelajaran yang didalamnya terdapat tujuan pembelajaran, materi, dan evaluasi serta disusun dan diatur agar dapat membantu mencapai tujuan pembelajaran (Pratiwi dan Martiana, 2017). Saran perbaikan yang diberikan oleh validator untuk aspek ini yaitu pada modul belum terdapat rubrik penilaian sehingga perlu diperbaiki.

Dan untuk aspek kebahasaan ini validator memberikan penilaian baik karena pada modul bahasa sudah menggunakan bahasa yang sesuai dengan Ejaan Yang Disesuaikan (EYD), dan struktur kalimat sudah tepat. Adapun saran dari validator yaitu sebaiknya bahasa yang digunakan pada modul lebih disesuaikan dengan siswa SMP misalnya dengan ditambahkan kalimat ajakan ataupun pertanyaan-pertanyaan. Sehingga modul dapat berperan sebagai guru/fasilitator serta dapat digunakan siswa secara mandiri. Sebagaimana salah satu karakteristik modul yaitu User Friendly, yang berarti bersahabat dengan pengguna. Segala informasi ataupun petunjuk yang disampaikan harus dapat membantu pengguna, misalnya menggunakan bahasa yang sederhana, dapat dipahami, serta menggunaakan bahasa yang umum. Pada cara penggunaan modul pembelajaran sebaiknya disampaikan dengan jelas agar siswa dapat mengikuti segala proses pembelajaran yang ada pada modul (Daryanto, 2013).

\section{KESIMPULAN}

Pengembangan modul permbelajaran berbasis multimedia dengan menggunakan Flip PDF Professional pada tema udara yang sehat ini dapat dilakukan dengan menggunakan model pengembangan Sugiyono melalui lima tahap, yaitu (1) potensi dan masalah, (2) pengumpulan data, (3) desain produk, (4) validasi desain, dan (5) perbaikan desain.

Hasil uji kevalidan modul berbasis multimedia dengan menggunakan Flip PDF Professional pada tema udara yang sehat ini berdasarkan validasi media mendapatkan nilai $89,4 \%$ dengan kategori sangat valid, dan untuk validasi materi mendapatkan nilai $86,9 \%$ yang berarti juga masuk ke dalam kategori sangat valid.

\section{DAFTAR PUSTAKA}

Arsal, M., Muhammad, D., dan Yusminah, H. (2019). Pengembangan Media Pembelajaran E-Modul Materi Sistem Peredaran Darah Pada Kelas IX MIPA SMAN 6 Barru. Prosiding Seminar Nasional Biologi VI, Hal: 434-442

Daryanto. (2013). Menyusun Modul Bahan Ajar untuk Persiapan Guru Dalam Mengajar. Yogyakarta: Gava Media.

Depdiknas. (2010). Pengembangan Bahan Ajar. Jakarta: Depdiknas

Flipbuilder. (2020). Flip PDF Professional. Diambil dari https://www.flipbuilder.com/flip-pdf-pro/ 
Hasanah dan Nulhakim. 2015. Pengembangan Media Pembelajaran Film Animasi Sebagai Media Pembelajaran Konsep Fotosintesis. Jurnal Penelitian dan Pembelajaran IPA, Vol. 1, No. 1, Hal. 91-106.

Indriana, Dina. (2011). Ragam Alat Bantu Media Pengajaran. Yogyakarta: DIVA Press.

Karli, Hilda. (2013). Head-Hand-Heart (3H) Dalam Kurikulum Berbasis Kompetensi. Bandung: Bina Media Informasi.

Novitasari, E., Mohammad M., dan Nonoh, S. (2016). Pengembangan Modul Pembelajaran IPA Terpadu Berbasis Inkuiri Terbimbing Tema Matahari Sebagai Sumber Energi Alternatif Di Kelas VII SMP/MTs. Jurnal Inkuiri, Vol. 5, No. 1, Hal: 112-121.

Pakpahan, Roida dan Yuni, F. (2020). Analisa Pemanfaatan Teknologi Informasi Dalam Pembelajaran Jarak Jauh Di Tengah Pandemi Virus Corona Covid-19. JISAMAR Journal of Information System, Applied, Management, Accounting and Reseach, Vol. 4, No. 2, Hal: 30-36.

Pratiwi, Hidayah N., dan Martiana, A. (2017). Pengembangan Modul Mata Kuliah Penilaian Pembelajaran Sosiologi Berorientasi HOTS. Cakrawala Pendidikan, Vol. 36, No. 2, Hal: 201-208.

Priambudi, Panji. (2018). Street Smart Slide Tips Praktis Mendesain Slide Presentasi Kelas Dunia. Malang: PT Litera Mediatama.

Putri, A., Sjaifuddin, dan Liska, B. (2022). Pengembangan E-Modul IPA Berbasis Adobe Flash Pada Tema Makananku Kesehatanku Untuk Kelas VIII SMP. PENDIPA Journal of Science Education, Vol. 6, No. 1, Hal: 143-150.

Rahayu, Wiwin Eka dan Sudarmin. (2015). Pengembangan Modul IPA Terpadu Berbasis Etnosains Tema Energi Dalam Kehidupan Untuk Menanamkan Jiwa Konservasi Siswa. Unnes Science Education Journal, Vol. 4, No. 2, Hal: 919-926.
Saputra, A., Sri, W., dan Rifati D. (2016). Pengembangan Modul IPA Berbasis Kearifan Lokal Daerah Pesisir Puger Pada Pokok Bahasan Sistem Transportasi Di SMP. Jurnal Pembelajaran Fisika, Vol. 5, No. 2, Hal: 182-189.

Seruni, Rara. dkk. (2019). Pengembangan Modul Elektronik (E-Modul) Biokimia Pada Materi Metabolisme Lipid Menggunakan Flip Pdf Professional. JTK: Jurnal Tadris Kimiya, Vol. 4, No. 1, Hal: 48-56.

Sriwahyuni, I., Eko, R., dan Henny, J. (2019). Pengembangan Bahan Ajar lektronik Menggunakan Flip Pdf Professional Pada Materi Alat-Alat Optik Di SMA. Jurnal Kumparan Fisika, Vol. 2, No. 3, Hal: 145-152.

Sugiyono. (2013). Metode Penelitian Pendidikan pendekatan Kuantitatif, Kualitatif dan $R \& D$. Bandung: Alfabeta.

Sulistiyawati, P., Dwi P. P., dan Dimas I. I. U., (2017). Perancangan Media Pembelajaran Berbasis Audio Visual Untuk Mata Kuliah Tipografi Pada Program Studi Desain Komunikasi Visual, Universitas Dian Nuswantoro. Andharupa, Vol. 3, No.1, Hal: 69-80.

Tania, Lisa dan Joni, S. (2017). Pengembangan Bahan Ajar E-Modul Sebagai Pendukung Pembelajaran Kurikulum 2013 Pada Materi Ayat Jurnal Penyesuaian Perusahaan Jasa Siswa Kelas X Akuntansi SMK Negeri 1 Surabaya. JPAK Jurnal Pendidikan Akuntansi, Vol. 5, No. 2, Hal: 1-9.

Wisudawati, W.A. dan Sulistyowati, E. (2014). Metode Pembelajaran IPA. Jakarta: Bumi Aksara.

Wulandari, Soesy S., Prabowo, dan Imam, S. (2018). Profil Pembelajaran Terpadu Pada Mata Pembelajaran IPA di Sekolah Menengah Pertama. Jurnal Inovasi dan Pembelajaran Fisika, Vol. 2, No. 1, Hal: 714. 